\title{
Diversity of benthic macroinvertebrates and water quality of Karasu Stream (Black Sea)
}

\section{Karasu Deresi’nin (Karadeniz) bentik makroomurgasız çeşitliliği ve su kalitesi}

\author{
Eylem Aydemir Çil1 $\bullet$ Murat Özbek ${ }^{2 *}$ • Öztekin Yardım ${ }^{3}$ • Seray Yıldız ${ }^{4}$ Ayşe Taşdemir ${ }^{5}$ \\ Hamidreza Rasouli6 $\bullet$ Pınar Gürbüzer ${ }^{7}$
}

\author{
${ }^{1}$ Department of Environmental Engineering Faculty of Engineering and Architecture, Sinop University Sinop, Turkey \\ 2 Department of Hydrobiology, Faculty of Fisheries, Ege University, İzmir, Turkey \\ ${ }^{3}$ Department of Hydrobiology, Faculty of Fisheries, Sinop University, Sinop, Turkey \\ ${ }^{4}$ Department of Hydrobiology, Faculty of Fisheries, Ege University, Izmir, Turkey \\ ${ }^{5}$ Department of Hydrobiology, Faculty of Fisheries, Ege University, İzmir, Turkey \\ ${ }^{6}$ Department of Hydrobiology, Faculty of Fisheries, Ege University, Izmir, Turkey \\ ${ }^{7}$ Department of Hydrobiology, Faculty of Fisheries, Sinop University, Sinop, Turkey
}

*Corresponding author: ozbekm71@gmail.com

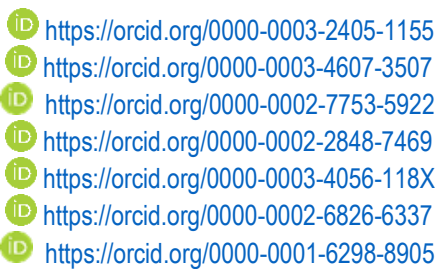

Received date: 31.03 .2021
Accepted date: 11.10 .2021

\section{How to cite this paper:}

Aydemir Çil, E., Özbek, M., Yardım, Ö., Yıldız, S., Taşdemir, A., Rasouli, H. \& Gürbüzer, P. (2021). Diversity of benthic macroinvertebrates and water quality of Karasu Stream (Black Sea). Ege Journal of Fisheries and Aquatic Sciences, 38(4), 467-477. DOI: 10.12714/egejfas.38.4.08

Abstract: The study was conducted in Karasu Stream (Sinop Province, Black Sea Region of Turkey). The purpose of this study is, to determine the benthic macroinvertebrate composition of the stream, together with some of its environmental characteristics (water temperature, $\mathrm{pH}$ and dissolved oxygen) to evaluate the trophic level of the stream. Samplings of benthic macroinvertebrates and environmental variables were performed monthly at ten stations between February 2013 and January 2014. As a result, 18260 specimens were investigated and 175 taxa were determined. Chironomidae and Oligochaeta were the higher groups in terms of species richness with 48 and 38 taxa, respectively. The BMWP and ASPT indices indicate that all the stations belong to "slightly polluted (Class II)" or "unpolluted (Class I)" water quality levels.

Keywords: Stream, water quality, benthos, macroinvertebrate, Turkey

Öz: Çalışma; Karasu Çayı'nda (Türkiye'nin Karadeniz Bölgesi, Sinop ïli) yürütülmüştür. Bu çalışmanın amacı, akarsuyun bentik makroomurgasız tür kompozisyonunu belirlemek, bazı çevresel özellikleri (su sıcaklığı, pH ve çözünmüş oksijen) ile birlikte akarsuyun trofik seviyesini değerlendirmektir. Makrobentik omurgasızların ve çevresel değişkenlerin örneklemesi, Şubat 2013 - Ocak 2014 tarihleri arasında 10 istasyonda aylık olarak gerçekleştirilmiştir. Sonuç olarak, 18260 örnek incelenmiş ve 175 takson belirlenmiştir. Tür zenginliği açısından Chironomidae ve Oligochaeta sırasıyla 48 ve 38 takson ile en yüksek gruplardır. BMWP ve ASPT endeksleri, tüm istasyonların "hafif kirli (Sınıf II)" veya "kirlenmemiş (Sınıf I)" su kalitesi seviyelerine ait olduğunu göstermektedir.

Anahtar kelimeler: Akarsu, su kalitesi, bentos, makroomurgasız, Türkiye

\section{INTRODUCTION}

The physico-chemical parameters can reflect temporary water quality levels of the region and cannot give reliable data about the amount of pollution in streams or rivers. Which can be helpful but insufficient when considering a long-term water quality assessment (Demir, 2005) but organisms such as macroinvertebrates, fish, etc. can be more adapted to a specific environment. Benthic macroinvertebrates constitute a major component of the aquatic biota in freshwater environments. Most of them have constricted ecological demands and are very beneficial as bioindicators in determining the characteristics of aquatic environments (Benetti and Garrido, 2010). They are the group of organisms most frequently used in biomonitoring studies of running waters because their responses to all kind of pollution have been extensively proven (Thorne and Williams, 1997).

Various studies have been conducted on the assessment of benthic macroinvertebrates in Sinop province (Akbulut,1996; Bat et al. 2000; Akbulut, 2001; Akbulut et al. 2001;2002; Ertorun and Tanatmış, 2004; Öktener, 2004; Tanatmış, 2004; Şendoğan, 2006; Tanatmış and Ertorun, 2008; Yardım et al. 2008; Aydemir-Çil, 2014; Yardım et al. 2017). There is no study carried out on the diversity of benthic macroinvertebrate of the Karasu Stream. 
The objective of this study is to determine both the benthic macro-invertebrate composition of the stream and some environmental parameters (water temperature, $\mathrm{pH}$, and dissolved oxygen) and to assess the ecological quality of the stream

\section{MATERIALS AND METHODS}

Karasu Stream, which has approximately $80 \mathrm{~km}$ in length, originates from Boyabat district, passes along Erfelek town in Sinop province, and flows into the Black Sea (Figure1). The stream and Erfelek Dam supply the drinking water of the surrounding settlements.

Environmental variables and benthic materials were sampled at 10 sites between February 2013 and January 2014 in monthly intervals (Figure 1, Table 1). In total, seven sites were located on the mainstream (two of them upstream the dam) and three sites were on tributaries. Karasu River flows into the Black Sea through an estuarine system, thus the sites $A 1$ and $A 2$ are under the influence of water from the sea in spring and winter due to waves and currents. The $A 3$ and $A 6$ sites are located on Karasu Creek, while the A4, $A 5$ and $A 7$ sites were selected from the tributaries of the stream. A9 and A10 were selected before the Erfelek Dam. The substrate types, vegetation, and geographic data of the sites are given in Table 1.

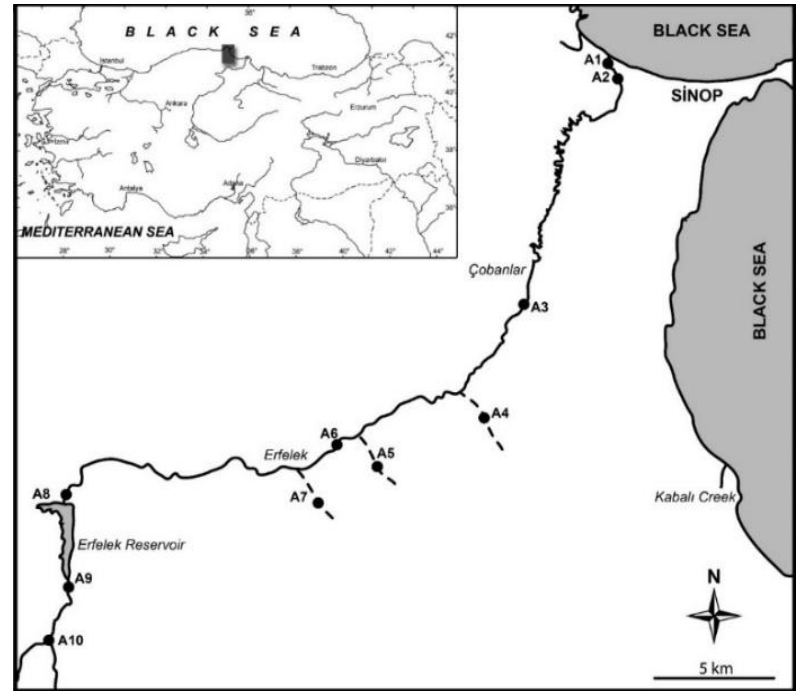

Figure 1. The geographical location of the study area (Karasu Stream) and the sampling sites.

The environmental variables were measured using Hanna $9829 \mathrm{HI}$ model multiparameter device. Samples were collected by the Kick-sampling method (Letovsky et al. 2012) from a $1 \mathrm{~m}^{2}$ area with a 5-minute collection standard (kick-net mesh size $180 \mu \mathrm{m})$.

Table 1. Geographical and ecological data about the sampling sites

\begin{tabular}{|c|c|c|c|c|c|}
\hline Station & Latitude & Longitude & Substrate Type & Depth(m) & Riparian Vegetations \\
\hline $\mathrm{A} 1$ & $42^{\circ} 01^{\prime} 56^{\prime \prime} \mathrm{N}$ & $35^{\circ} 03^{\prime} 33^{\prime \prime} \mathrm{E}$ & sand and mud & $0-4 \mathrm{~m}$ & grassland and reedbed \\
\hline $\mathrm{A} 2$ & $42^{\circ} 01^{\prime} 52^{\prime \prime} \mathrm{N}$ & $35^{\circ} 03^{\prime} 34^{\prime \prime} \mathrm{E}$ & sand and mud & $0-4 \mathrm{~m}$ & grassland and reedbed \\
\hline A3 & $41^{\circ} 55^{\prime} 05^{\prime \prime} \mathrm{N}$ & $35^{\circ} 06^{\prime} 14^{\prime \prime} \mathrm{E}$ & stone and mud & $0-1 \mathrm{~m}$ & grassland and moss \\
\hline A4 & $41^{\circ} 54^{\prime} 16 " \mathrm{~N}$ & $34^{\circ} 59^{\prime} 49^{\prime \prime} \mathrm{E}$ & mud & $0-0.5 \mathrm{~m}$ & grassland \\
\hline A5 & $41^{\circ} 53^{\prime} 32^{\prime \prime} \mathrm{N}$ & $34^{\circ} 56^{\prime} 04^{\prime \prime} \mathrm{E}$ & mud & $0-0.5 \mathrm{~m}$ & grassland \\
\hline A6 & $41^{\circ} 52^{\prime} 46 " \mathrm{~N}$ & $34^{\circ} 51 ' 23 " E$ & stone and mud & $0-0.5 \mathrm{~m}$ & grassland and Chara sp. \\
\hline A7 & $41^{\circ} 52^{\prime} 59^{\prime \prime} \mathrm{N}$ & $34^{\circ} 47^{\prime} 45^{\prime \prime} \mathrm{E}$ & rocks and mud & $0-1 \mathrm{~m}$ & grassland and green algae \\
\hline A8 & $41^{\circ} 50^{\prime} 53^{\prime \prime} \mathrm{N}$ & $34^{\circ} 46^{\prime} 31^{\prime \prime} \mathrm{E}$ & calcareous rocks & $0-0.5 \mathrm{~m}$ & - \\
\hline A9 & $41^{\circ} 50^{\prime} 26 " \mathrm{~N}$ & $34^{\circ} 46^{\prime} 47^{\prime \prime E}$ & mud & $0-0.5 \mathrm{~m}$ & grassland and Astiboles sp. \\
\hline $\mathrm{A} 10$ & $41^{\circ} 49^{\prime} 24^{\prime \prime} \mathrm{N}$ & $34^{\circ} 46^{\prime} 17^{\prime \prime} \mathrm{E}$ & rocks and mud & $0-1 \mathrm{~m}$ & grassland and moss \\
\hline
\end{tabular}

The samples were transferred into $500-1000 \mathrm{ml}$ plastic jars and fixed in $4 \%$ formalin solution in the field. Then, in the laboratory, the collected materials were washed under tap water to remove formaldehyde and filtered through 0.5- and 1-mm sieves to sort the macroinvertebrates based on size. The, organisms were transferred into small jars with $75 \%$ ethanol solution.

Fauna Europaea (2021) database was used for the current names of the taxa. All the macroinvertebrate samples were identified to the genera-species level whenever possible.
The Index of Diversity (H') (Shannon and Weaver, 1949), Pielou's Evennes Index (J') (Pielou, 1975), Similarity Index (Brayand Curtis, 1957), frequency (Soyer, 1970), and dominance values (Bellan-Santini, 1969) of the determined taxa were calculated and used to describe the characteristics of the sites and Karasu Stream. For assessing the water quality of the studied locations, Biological Monitoring Working Party (BMWP) scores (Paisley et al. 2013) and Average Score Per Taxon (ASPT) (Armitage et al. 1983) were calculated. These scores were obtained from ASTERICS 3.3.1 (AQEM/STAR Ecological River Classification System; AQEM Consortium 2002) software. 
The similarity of the studied localities followed by cluster analysis (UPGMA, Unweighted Pair Group Average) was calculated starting from the quantitative data of the macroinvertebrate taxa; the Multivariate Statistical Package (MVSP) program version 3.1 (Kovach, 1998) was used to perform the cluster analysis.

The results of the physico-chemical measurements and biological analysis were evaluated according to the National Surface Water Quality Regulations of Republic of Turkey Ministry of Agriculture and Forestry (Anonymous, 2016) to classify the water quality levels of the sites.

\section{RESULTS}

\section{Environmental variables}

During the study, the lowest water temperature $\left(4.06^{\circ} \mathrm{C}\right.$, in February) was observed at the $A 5$ station while the highest (27.6 ${ }^{\circ} \mathrm{C}$, in August) was measured at $\mathrm{A} 1$ and $\mathrm{A} 2$ sites. The dissolved oxygen value (DO) was the highest at the $A 1$ station (17.7 mg/l, in April) and the lowest at the A4 station (1.07 mg/l, in July). Similarly, the highest $\mathrm{pH}$ value was observed at the A2 station (11.62) in January and the lowest at the A10 station (6.18) in May. The general pattern of the $\mathrm{pH}$ values suggests that Karasu Stream has a slightly alkaline character (Table 2).
Table 2. Maximum and minimum values of the measured environmental variables ( $\mathrm{T}$ : water temperature, DO: dissolved oxygen)

\begin{tabular}{lccc}
\hline Months & $\mathbf{T}\left({ }^{\circ} \mathrm{C}\right)$ & $\mathbf{p H}$ & $\mathrm{DO}(\mathrm{mg} / \mathrm{l})$ \\
\hline February & $4.06-6.73$ & $8.09-8.48$ & $5.7-8.3$ \\
March & $4.08-8.03$ & $8.27-10.44$ & $9.18-11.32$ \\
April & $6.66-10.9$ & $7.48-8.39$ & $10.7-11.7$ \\
May & $8.34-14.7$ & $6.18-8.57$ & $8.09-11.1$ \\
June & $7.81-14.8$ & $8.3-9.17$ & $4.8-8.76$ \\
July & $7.5-17.2$ & $7.92-8.41$ & $1.07-8.5$ \\
August & $12.7-27.6$ & $7.79-8.85$ & $1.24-5.47$ \\
September & $12.7-24.6$ & $7.64-8.27$ & $3.7-9.7$ \\
October & $13.6-27.5$ & $8.18-9.04$ & $1.9-10.4$ \\
November & $11.2-16$ & $7.55-8.55$ & $5.5-10.3$ \\
December & $9.42-14.93$ & $7.75-8.46$ & $10.1-11.8$ \\
January & $7.83-8.53$ & $7.19-11.98$ & $5.3-8.4$ \\
\hline
\end{tabular}

\section{Benthic macroinvertebrates}

In total 18,260 individuals belonging to 175 taxa were determined. Almost all of them (170 taxa) except for that of Ephemeroptera (5 taxa were reported by Ertorun and Tanatmış, 2004) are new records for the Karasu Stream. The benthic macroinvertebrates diversity of the stream consisted of Mollusca (12 taxa, 860 ind.), Oligochaeta (38 taxa, 1157 ind.), Malacostraca (11 taxa, 10568 ind.), Ostracoda (7 taxa, 65 ind.), Hexapoda (26 taxa, 2437 ind.), Trichoptera (20 taxa, 151 ind), Chironomidae (48 taxa, 595 ind.) and other Dipterans (13 taxa, 2427 ind.) (Figure 2). The family of Chironomidae has the highest number of taxa among the groups. The list of the identified taxa and their occurrence, dominancy and frequency values per station are given in Table 3.

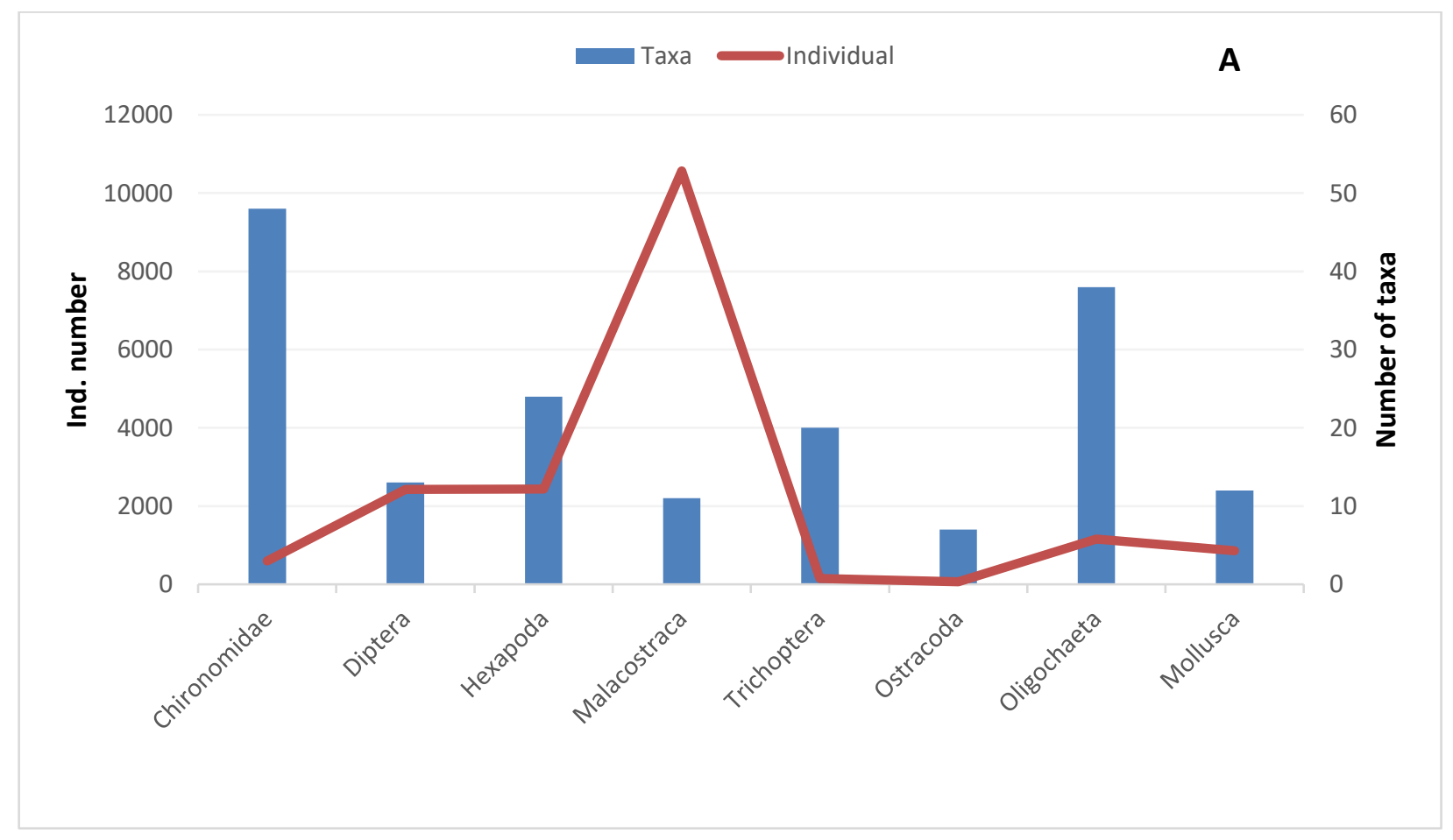




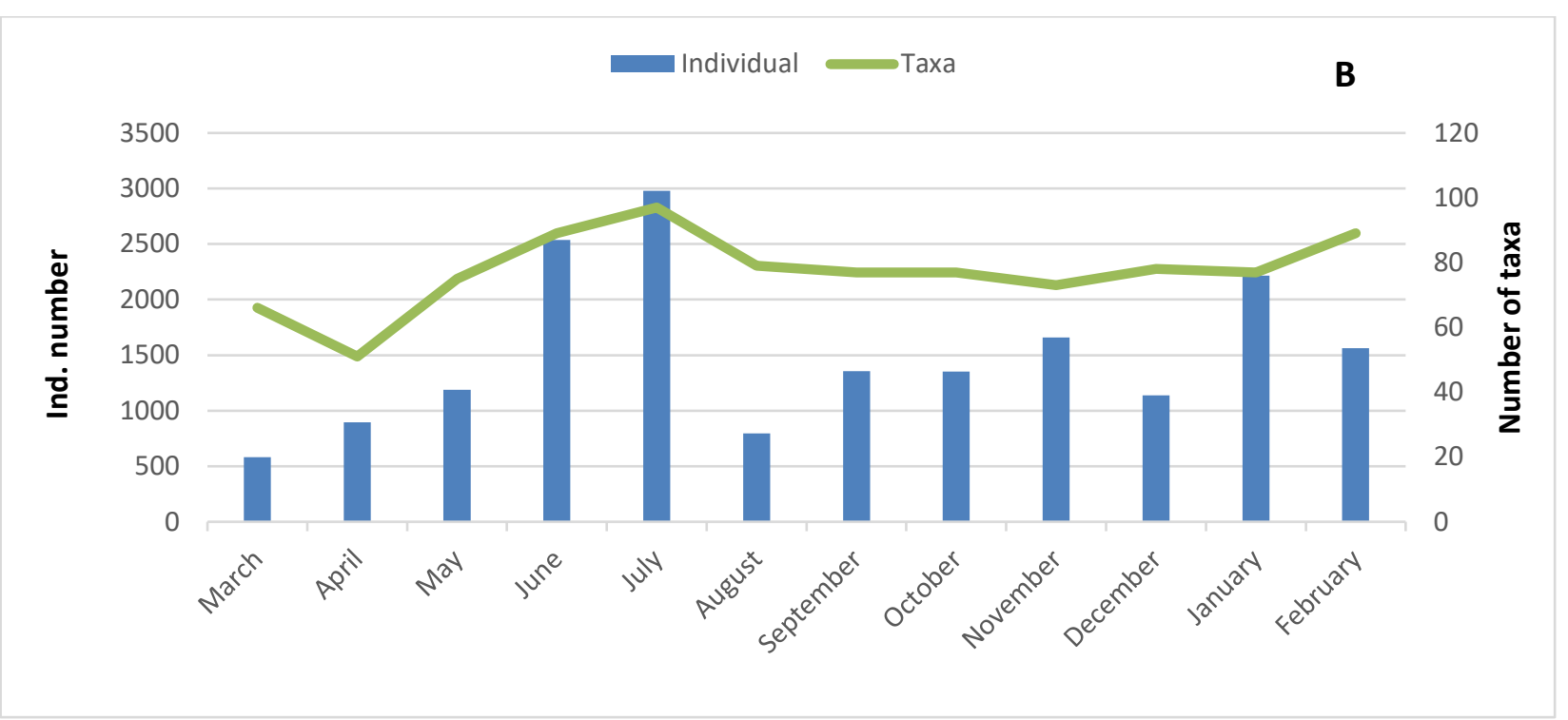

Figure 2. The number of individuals and taxa of the identified systematic groups for the whole study (A), and in time scale (B).

Table 3. List of the identified taxa and their annual abundance (ind $\left./ \mathrm{m}^{2}\right)$, dominance $(\% \mathrm{D})$, and frequency $(\% \mathrm{~F})$ values at the sites (Ent.: Entomobryomorpha; Dec.: Decapoda).

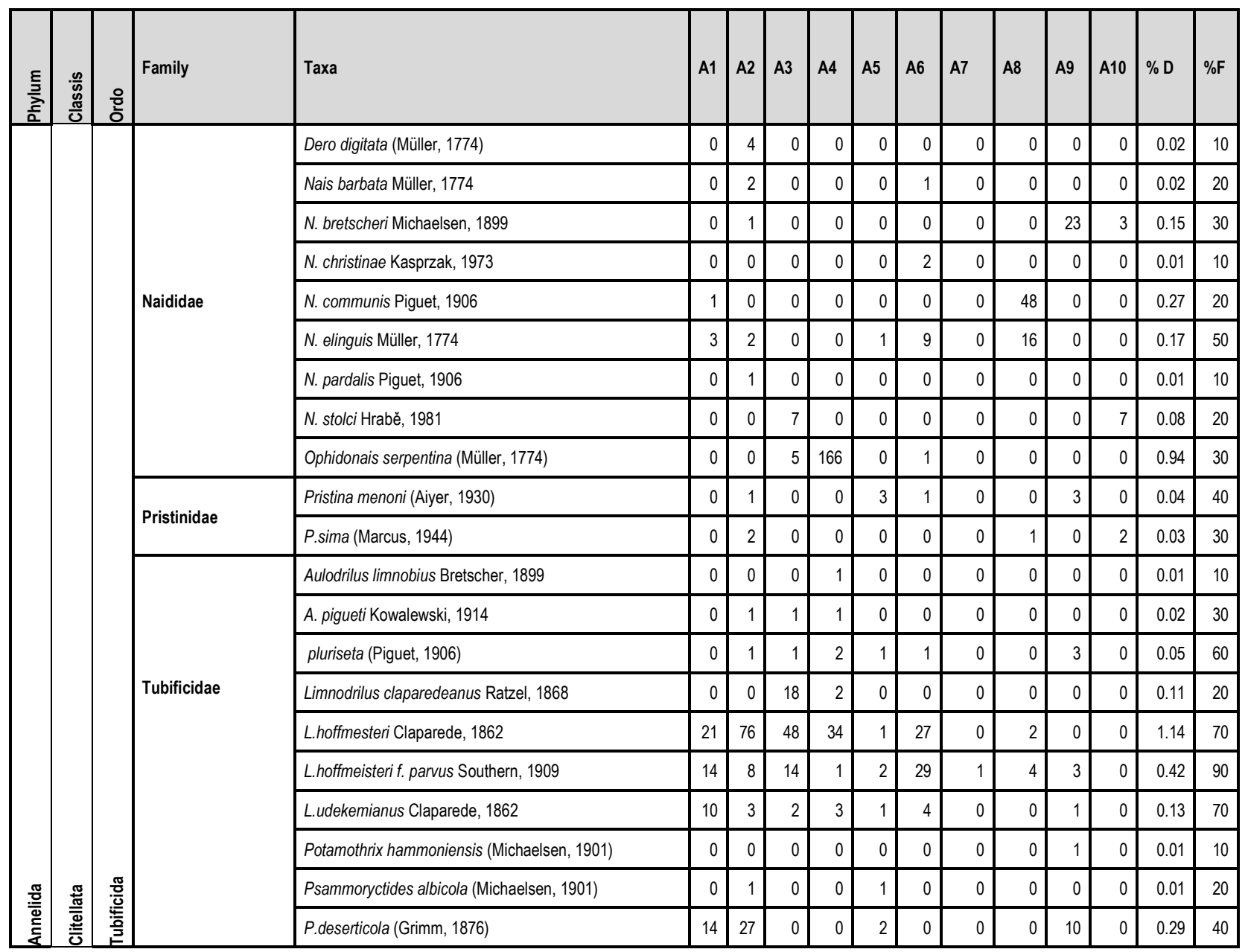




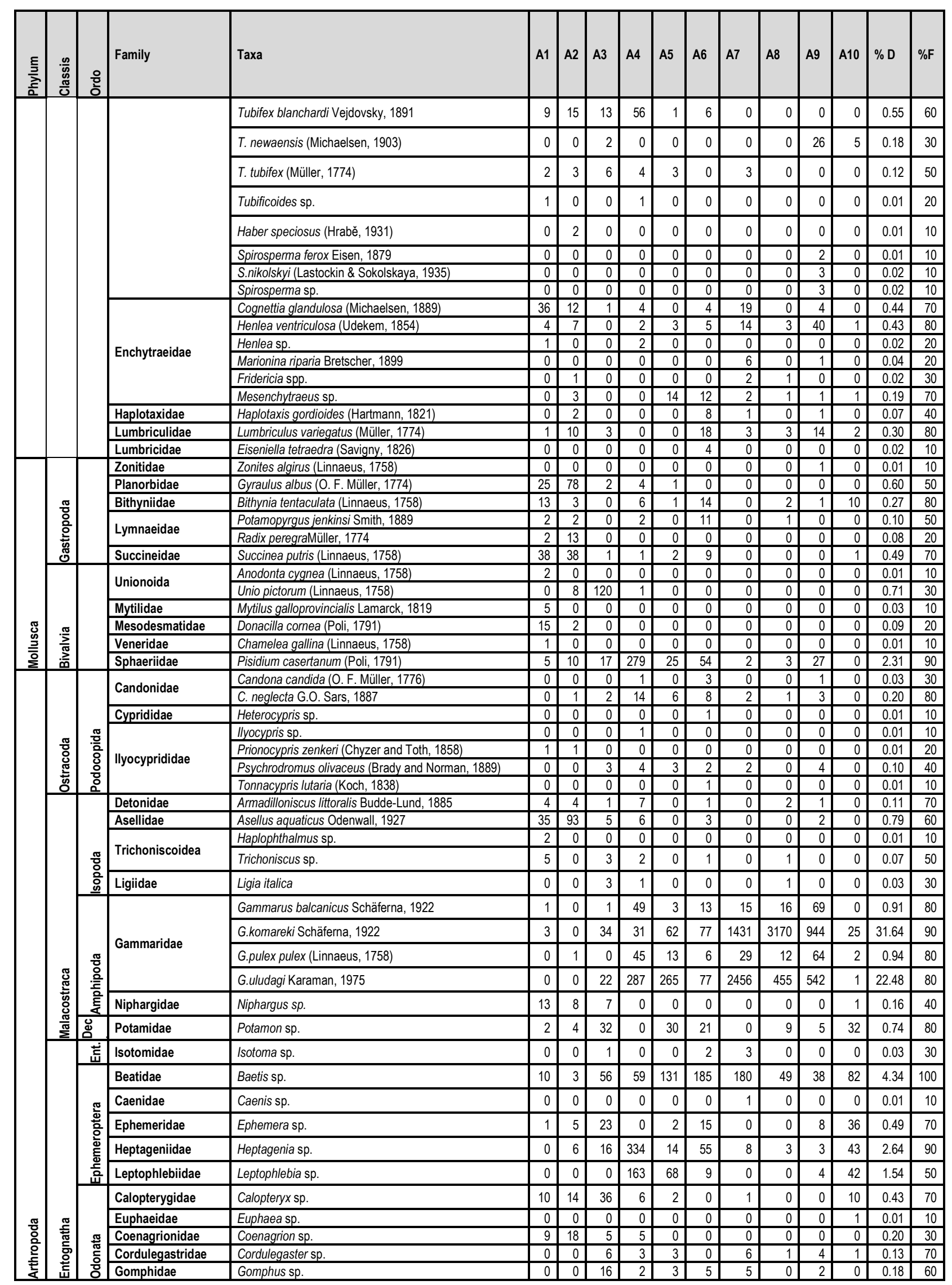




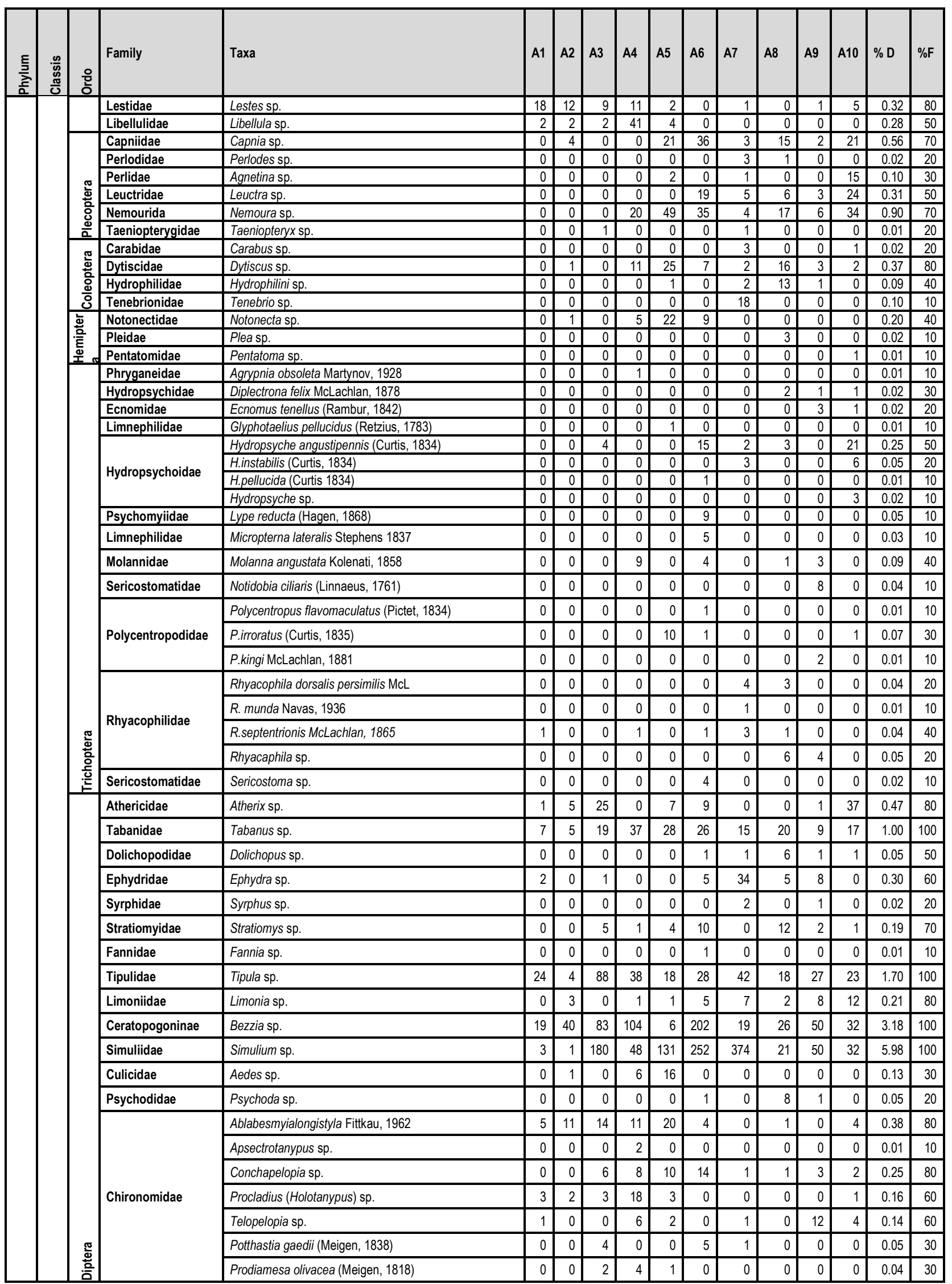




\begin{tabular}{|c|c|c|c|c|c|c|c|c|c|c|c|c|c|c|c|c|}
\hline$\underset{\frac{E}{\bar{z}}}{\underline{\underline{a}}}$ & $\begin{array}{l}\frac{\omega}{\omega} \\
0 \\
\frac{\pi}{0}\end{array}$ & 은 & Family & Taxa & A1 & A2 & A3 & A4 & A5 & A6 & A7 & A8 & A9 & A10 & $\% \mathrm{D}$ & $\% \mathrm{~F}$ \\
\hline & & & & Brillia flavifrons (Johannsen, 1905) & 1 & 0 & 6 & 0 & 0 & 0 & 0 & 0 & 2 & 3 & 0.07 & 40 \\
\hline & & & & B.modesta (Meigen, 1830) & 0 & 0 & 0 & 3 & 7 & 5 & 10 & 6 & 10 & 2 & 0.24 & 70 \\
\hline & & & & Cardiocladius fuscus Kieffer, 1924 & 0 & 0 & 0 & 0 & 0 & 0 & 0 & 1 & 0 & 0 & 0.01 & 10 \\
\hline & & & & Cricotopus sp. & 4 & 4 & 5 & 5 & 0 & 4 & 2 & 1 & 5 & 3 & 0.18 & 90 \\
\hline & & & & Cricotopus sylvestris (Fabricius, 1794) & 2 & 1 & 0 & 0 & 0 & 0 & 0 & 0 & 0 & 0 & 0.02 & 20 \\
\hline & & & & C.triannulatus Macquart, 1826 & 0 & 0 & 0 & 0 & 0 & 2 & 0 & 0 & 0 & 0 & 0.01 & 10 \\
\hline & & & & Eukiefferiella sp. & 1 & 0 & 2 & 0 & 1 & 1 & 0 & 0 & 3 & 3 & 0.06 & 40 \\
\hline & & & & Eukiefferiella claripennis (Lunnbeck, 1898) & 1 & 1 & 1 & 0 & 0 & 0 & 0 & 0 & 0 & 0 & 0.02 & 30 \\
\hline & & & & E.gracei (Edwards, 1929) & 0 & 0 & 0 & 0 & 0 & 1 & 0 & 0 & 1 & 0 & 0.01 & 20 \\
\hline & & & & Orthocladius sp. & 2 & 0 & 1 & 0 & 1 & 1 & 0 & 0 & 0 & 2 & 0.04 & 40 \\
\hline & & & & Parametriocnemus sp. & 1 & 0 & 1 & 0 & 1 & 1 & 0 & 1 & 1 & 0 & 0.03 & 60 \\
\hline & & & & Paratrissocladius sp. & 0 & 0 & 1 & 0 & 0 & 0 & 0 & 0 & 0 & 0 & 0.01 & 10 \\
\hline & & & & Psectrocladius sp. & 0 & 0 & 0 & 0 & 0 & 0 & 0 & 0 & 1 & 0 & 0.01 & 10 \\
\hline & & & & Rheocricotopus fuscipes Kieffer, 1909 & 0 & 0 & 1 & 0 & 0 & 0 & 0 & 1 & 0 & 0 & 0.01 & 20 \\
\hline & & & & Rheocricotopus sp. & 0 & 0 & 4 & 1 & 6 & 1 & 9 & 1 & 4 & 0 & 0.14 & 70 \\
\hline & & & & Smittia sp. & 1 & 1 & 2 & 0 & 0 & 0 & 1 & 0 & 0 & 0 & 0.03 & 40 \\
\hline & & & & Thienemannimyia sp. & 0 & 0 & 4 & 2 & 3 & 7 & 1 & 2 & 7 & 2 & 0.15 & 80 \\
\hline & & & & Tvetenia sp. & 0 & 0 & 0 & 0 & 1 & 0 & 1 & 0 & 0 & 0 & 0.01 & 20 \\
\hline & & & & Chironomus sp. & 8 & 8 & 6 & 8 & 10 & 3 & 0 & 0 & 4 & 2 & 0.27 & 80 \\
\hline & & & & Cryptochironomus denticulatus (Goetghebuer, 1921) & 0 & 0 & 1 & 0 & 0 & 0 & 0 & 0 & 0 & 0 & 0.01 & 10 \\
\hline & & & & Dicrotendipes lobiger (Kieffer, 1921) & 0 & 1 & 0 & 5 & 3 & 0 & 0 & 0 & 0 & 0 & 0.05 & 30 \\
\hline & & & & D.nervosus (Stæger, 1839) & 2 & 1 & 0 & 5 & 0 & 0 & 0 & 1 & 0 & 0 & 0.05 & 40 \\
\hline & & & & D.notatus (Meigen, 1818) & 1 & 1 & 0 & 0 & 1 & 0 & 0 & 0 & 0 & 0 & 0.02 & 30 \\
\hline & & & & Endochironomus dispar (Meigen, 1830) & 4 & 5 & 0 & 5 & 2 & 0 & 2 & 0 & 1 & 0 & 0.10 & 60 \\
\hline & & & & E.lepidus (Meigen, 1830) & 1 & 0 & 0 & 2 & 2 & 0 & 0 & 0 & 0 & 0 & 0.03 & 30 \\
\hline & & & & Endochironomus sp. & 2 & 1 & 0 & 1 & 0 & 0 & 0 & 0 & 1 & 0 & 0.03 & 40 \\
\hline & & & & Kiefferulus sp. & 4 & 7 & 0 & 12 & 3 & 0 & 0 & 0 & 0 & 0 & 0.14 & 40 \\
\hline & & & & Microtendipes pedullus (De Geer, 1776) & 0 & 0 & 1 & 1 & 1 & 0 & 0 & 2 & 1 & 0 & 0.03 & 50 \\
\hline & & & & Phaenopsectra sp. & 1 & 1 & 0 & 1 & 2 & 0 & 0 & 0 & 0 & 0 & 0.03 & 40 \\
\hline & & & & Polypedilum laetum (Meigen, 1818) & 0 & 2 & 2 & 0 & 1 & 0 & 0 & 0 & 1 & 2 & 0.04 & 50 \\
\hline & & & & P.albicorne (Meigen, 1838) & 0 & 0 & 0 & 0 & 0 & 1 & 0 & 2 & 0 & 0 & 0.02 & 20 \\
\hline & & & & P.convictum (Walker, 1856) & 0 & 0 & 0 & 0 & 0 & 0 & 1 & 1 & 0 & 1 & 0.02 & 30 \\
\hline & & & & P.nubeculosum Meigen, 1804 & 2 & 2 & 0 & 0 & 0 & 0 & 0 & 0 & 0 & 0 & 0.02 & 20 \\
\hline & & & & P.pedestre (Meigen, 1830) & 0 & 1 & 2 & 0 & 1 & 1 & 0 & 0 & 1 & 0 & 0.03 & 50 \\
\hline & & & & P.scalaenum (Schrank, 1803) & 0 & 0 & 1 & 0 & 0 & 0 & 0 & 0 & 0 & 0 & 0.01 & 10 \\
\hline & & & & P.tritum (Walker, 1856) & 1 & 1 & 0 & 0 & 0 & 0 & 0 & 0 & 0 & 0 & 0.01 & 20 \\
\hline & & & & P.uncinatum (Goetghebuer, 1921) & 1 & 1 & 0 & 0 & 0 & 0 & 0 & 0 & 0 & 1 & 0.02 & 30 \\
\hline & & & & Polypedilum sp. & 6 & 10 & 1 & 0 & 1 & 0 & 0 & 0 & 1 & 5 & 0.13 & 60 \\
\hline & & & & Micropsectra sp. & 0 & 0 & 0 & 0 & 1 & 2 & 1 & 0 & 3 & 1 & 0.04 & 50 \\
\hline & & & & Paratanytarsus sp. & 0 & 2 & 1 & 0 & 2 & 0 & 0 & 0 & 0 & 1 & 0.03 & 40 \\
\hline & & & & Tanytarsus sp. & 0 & 2 & 2 & 4 & 1 & 0 & 1 & 2 & 0 & 0 & 0.07 & 60 \\
\hline
\end{tabular}

According to Soyer's frequency index, 175 taxa were observed continuously all year long (Table 3 ). The highest number of taxa was determined in July (98 taxa), June $(90$ taxa), and February (89 taxa), while the least in April (52 taxa). The highest number of individuals was sampled in July $\left(2986\right.$ ind. $\left./ \mathrm{m}^{2}\right)$ and June $\left(2539\right.$ ind. $\left./ \mathrm{m}^{2}\right)$, while the lowest in March (589 ind. $\left./ \mathrm{m}^{2}\right)$ (Figure 2).
$A 1$ and $A 2$ sites were located near the mouth of the stream, thus the sampled benthic organisms consist of mainly salinity-tolerant taxa such as $N$. pardalis, $P$. jenkinsi, $D$. cornea, M. galloprovincialis, C. gallina, T. blanchardi, and T. tubifex. Similarly, A3, A4, A5, and A6 sites were in the middle part of the stream where pure freshwater forms were observed (such as G. albus, L. hoffmeisteri, $H$. ventriculosa, 
S. putris, G. uludagi, and G. pulex pulex). A7, A8, A9, and A10 sites were in the upper part of the stream and are the cleanest ones because of the lack of pollutants around them. G. balcanicus and G. uludagi were the two typical taxa at these sites.

G. komareki has the highest dominance among the determined species with $31.64 \%$ and was followed by $G$. uludagi with $22.48 \%$. Individuals belonging to the orders of Hemiptera and Trichoptera with dominance of $0.01 \%$, also make up the least common groups.

The dominant taxon of $\mathrm{A} 1$ and $\mathrm{A} 2$ was $A$. aquaticus. All the dominant taxa observed at these sites are tolerant to organic pollution. The bottom of the A3 station consists of stone, gravel, and sand and the flow rate of water varies significantly throughout the year. The dominant taxa at the station were Simulium sp. and $U$. pictorum. A4 and A5 are creeks that join the Karasu Stream, and they have a rich riparian zone. The villages near the creeks were the main pollutants because of discharging wastes. The dominant taxa of these sites were G. uludagi and P. casertanum. The latter is cosmopolitan and euryoecious, which is mostly found in oligo- or beta-mesosaprobic freshwater environment (Subba Rao, 1989). Karasu River at site A6 passes through a sparse forest with a low flow rate, it has shallow with a stony-gravelly bottom and a dense Chara sp. population. Simulium sp., Bezzia sp., G. komareki, and G. uludagi were the dominant taxa at the station. A7 has 1-1.5 m depth, a rocky and stony bottom with rich terrestrial and aquatic plants. G. uludagi and G. komareki were the dominant taxa at the station. A8 was a small, clean waterfall outflowing to a reservoir near Erfelek town. The bottom of the station has rocks, stones, and pebbles. G. komareki, G. uludagi, and Baetis sp. were the dominant taxa at the station. A9 has a sandy bottom and is located near the Tatlica Waterfall. The dominant taxa of the station were G. komareki, G. uludagi, Bezzia sp., and Simulium sp. A10, which has a rocky and stony bottom, is located above the Tatlıca Waterfall. The dominant taxa of these sites were $G$. komareki and $G$. uludagi.

\section{Biological indices}

According to BMWP scores, the water quality of the sites A4, $A 5, A 6, A 9$, and $A 10$ was of the first class. Only around the sites of $A 1, A 2$, and $A 3$, settlements and agricultural activities occur; the other localities are not under the pressure of such negative effects. Results of BMWP analysis showed that A1, $A 2, A 3, A 7$, and $A 8$ sites were classified in slightly polluted (Class II) groups. Similarly, ASPT analysis indicated that A1, $A 2, A 6$, and $A 8$ were in the third class while the remaining ones in the second class (Table 4).

Table 4. The BMWP and ASPT scores and diversity indices of the sites (S: Total number of taxa, N: Total number of individuals, D: Margalef Species Richness, J': Pielou's Evenness Index, $H^{\prime}$ : Shannon-Weiner Diversity Index, $1-\lambda$ ': Simpson Index of Diversity)

\begin{tabular}{|c|c|c|c|c|c|c|c|c|c|c|c|c|}
\hline \multirow[b]{3}{*}{$\mathrm{A} 1$} & \multirow{2}{*}{$\begin{array}{l}\text { BMWP } \\
\text { Score value }\end{array}$} & & & \multicolumn{3}{|l|}{ ASPT } & \multicolumn{6}{|c|}{ Diversity Indices } \\
\hline & & \multicolumn{2}{|c|}{ Quality class } & \multirow{2}{*}{$\begin{array}{l}\text { Score value } \\
4.6\end{array}$} & \multicolumn{2}{|c|}{ Quality class } & \multirow{2}{*}{$\begin{array}{l}\text { S } \\
68\end{array}$} & \multirow{2}{*}{$\begin{array}{l}\mathbf{N} \\
453\end{array}$} & \multirow{2}{*}{$\begin{array}{l}\text { D } \\
10.96\end{array}$} & \multirow{2}{*}{$\begin{array}{l}J^{\prime} \\
0.85\end{array}$} & \multirow{2}{*}{$\begin{array}{l}\mathrm{H}^{\prime} \\
3.59\end{array}$} & \multirow{2}{*}{$\begin{array}{l}1-\lambda^{\prime} \\
0.96\end{array}$} \\
\hline & 111 & II. & Good & & III. & Poor & & & & & & \\
\hline $\mathrm{A} 2$ & 144 & II. & Good & 4.6 & III. & Poor & 77 & 642 & 11.76 & 0.77 & 3.36 & 0.94 \\
\hline A3 & 144 & II. & Good & 5.1 & II. & Fair & 72 & 1024 & 10.24 & 0.75 & 3.21 & 0.93 \\
\hline A4 & 159 & I. & Excellent & 5.1 & Il. & Fair & 74 & 2030 & 9.59 & 0.69 & 2.96 & 0.91 \\
\hline A5 & 170 & I. & Excellent & 5.3 & II. & Fair & 74 & 1102 & 10.42 & 0.69 & 2.98 & 0.90 \\
\hline A6 & 180 & I. & Excellent & 4.8 & III. & Poor & 80 & 1445 & 10.86 & 0.73 & 3.19 & 0.92 \\
\hline A7 & 143 & II. & Good & 5.1 & II. & Fair & 60 & 4774 & 6.96 & 0.35 & 1.45 & 0.64 \\
\hline A8 & 141 & II. & Good & 4.7 & III. & Poor & 60 & 4033 & 7.11 & 0.25 & 1.01 & 0.37 \\
\hline A9 & 189 & I. & Excellent & 5.2 & Il. & Fair & 78 & 2119 & 10.05 & 0.48 & 2.10 & 0.73 \\
\hline A10 & 175 & I. & Excellent & 5.5 & II. & Fair & 60 & 638 & 9.14 & 0.81 & 3.31 & 0.95 \\
\hline
\end{tabular}

Both Shannon-Weiner and Simpson indices resulted in high scores. Station $A 1$ has the highest diversity value $\left(H^{\prime}=3.59\right)$, while station $A 8$ has the lowest $\left(H^{\prime}=1.01\right)$. Nearly all the sites have high values in terms of richness but $A 2$ has the highest taxa while A7 has the lowest. Similarly, the evenness index suggested that $A 2$ has the highest score $\left(J^{\prime}=0.85\right)$ while station $A 8$ has the lowest $\left(J^{\prime}=0.25\right)$ (Table 4$)$.
The UPGMA analysis grouped the sites with a similarity of more than $50 \%$ according to the occurred taxa. In general, all the localities have high level of similarities (more than $50 \%$ ) to each other. A10 (with a stony and gravel bottom) was out grouped from the others. A7 and $A 8$, which have a rocky bottom, were grouped; both were separated from all the other sites except A10 and constitute another group. Within this group, A1 and A2 constituted a separate group with almost 70 
$\%$ similarity. Both sites are in the Abramis zone (lower part of the stream) and have a slightly brackish character. The other group was constituted by the remaining sites, which are purely freshwater. A3 with a stony and muddy bottom was separated within this group. Although the bottom structure of the other sites $A 4, A 5, A 6$, and $A 9$ were different, all have a muddy bottom and similarities in terms of faunal components; they form another cluster (Figure 3).

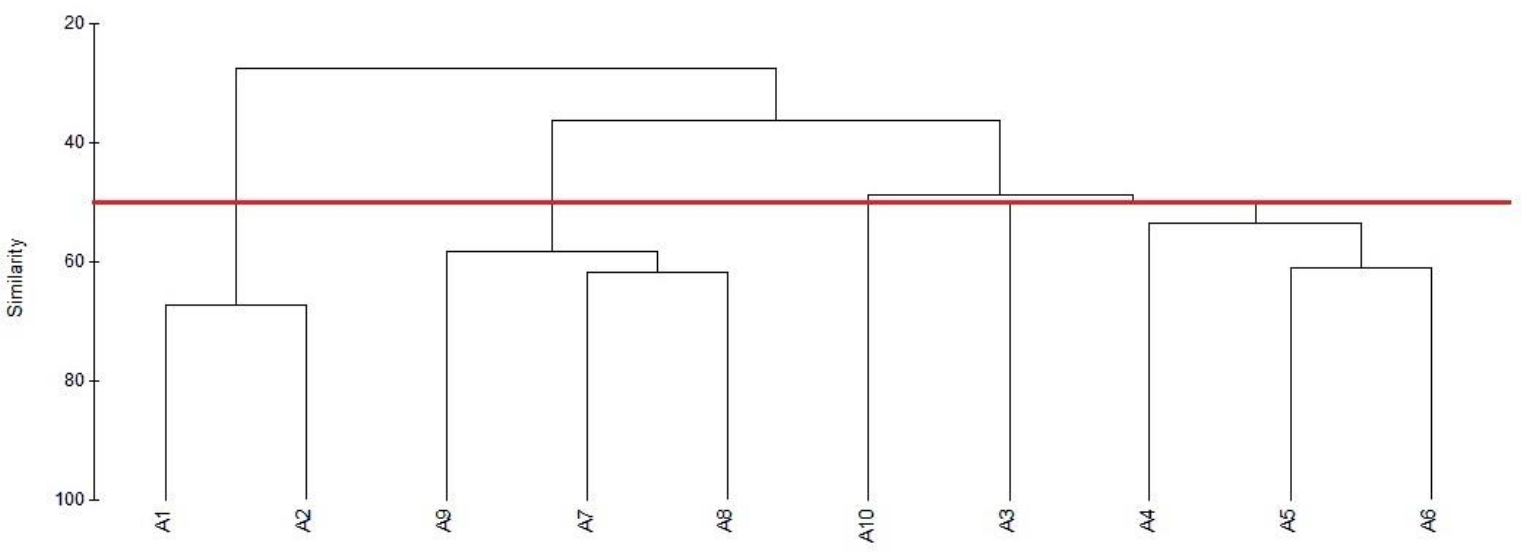

Figure 3. The UPGMA dendrogram showing the similarity of the sites

\section{DISCUSSION}

Long-term changes in water quality can be estimated more accurately if biological indicators are used as they are adapted to specific environmental conditions for a long time. For this reason, if any changes occur in running waters, they can be detected using the compositions and structures of aquatic organisms (Zamora-Muñoz and Alba-Tercedor, 1996).

In general, diverse and productive fish and macroinvertebrate communities prefer slightly alkaline aquatic environments, where $\mathrm{pH}$ values were between 6.5 and 8.5 (NAS, 1972). High pH and low oxygen concentrations have a lethal effect on living organisms (Tanyolaç, 2004). By having slight alkaline character, Karasu Stream offers a comfortable settlement for various benthic macroinvertebrate species.

Water temperature and dissolved oxygen values were the determinant factors in species richness at the sites. Pollutionsensitive taxa or clean water indicator species were observed frequently at the $A 4, A 5, A 6, A 9$, and $A 10$ sites, where diversity values were high andwater quality levels were in first class.

Climate and regions are the main predictors for the temperature periodicity patterns (Ward, 1985) and seasonality may become weak or harsh according to locations of the stream (e.g. Hopkins, 1971). The water temperature of the sites varies between $4.06-27.6^{\circ} \mathrm{C}$ throughout the year and is within the seasonal norms.
Macroinvertebrates inhabit different parts of a waterbody. They can live in the sediment or water's surface, water itself, etc. Environmental conditions such as submerged rocks, leaf litter, or water velocity can be determinant which macroinvertebrates can live (Tanyolaç, 2004).

The BMWP and ASPT scores are frequently used to determine the stream quality. Biological indices are usually specific for certain types of pollution since they are based on the presence or absence of indicators organisms, which are unlikely to be equally sensitive to all types of pollution. They are considered the sensitivities of macroinvertebrates to pollution and the BMWP scores give the how much clean or polluted the sites (Chapman, 1996). In the present study, the BMWP scores, suggested that all of the localities have high (more than 100) scores and it means all of them are in good (even excellent) conditions. On the other hand, the results of ASPT indicated that A1, A2 and A8sites were in poor conditions while the other ones in fair conditions.

The content of the species is expected to have high similarities at successive sampling sites, such as A1-A2 and A7-A8 or A5-A6. Because habitat transitions are close to one another, species compositions may be similar (Figure 3). Although A3 and A10 stations are far from each other in terms of location, they have high similarity to each other. Having similar environmental characteristics such as water depth, bottom structure, presence of riparian vegetation can be main reason for the high similarity. 
The species compositions expected to have high similarities at successive sampling sites, such as A1-A2 and A7-A8 or A5-A6. Because habitat transitions are close to one another, species compositions may be similar (Figure 3). Although $\mathrm{A} 3$ and $\mathrm{A} 10$ stations are far from each other in terms of location, they have high similarity to each other. Having similar environmental characteristics such as water depth, bottom structure, presence of riparian vegetation can be main reason for the high similarity. In addition, both sites have natural environmental conditions, isolated from roads and settlements.

A6 has the highest species richness (82 taxa). Rich riparian zone, diverse bottom structure (stone, gravel, sand, and mud), and relatively low water flow rates can be the main reasons for the higher macroinvertebrate diversity at the station. Reversely, A7 (with 62 taxa) has the lowest species richness where weak aquatic vegetation, rocky bottom, and rapid water flow occur. The main restrictive factor for species diversity at the station can be the high velocity of water flow.

\section{REFERENCES}

Akbulut, M. (1996). A preliminary research on macrobenthic fauna in Sarıkum Lake and surrounding puddles of Sinop province. Sinop University Institute of Natural and Applied Sciences, Faculty of Fisheries, MSc thesis.

Akbulut, M., (2001). A research on Malacostraca (Crustacea-Arthropoda) fauna in the inland waters of Samsun and Sinop provinces. Ege University Institute of Natural and Applied Sciences, Faculty of Fisheries, $\mathrm{PhD}$ thesis.

Akbulut, M., Sezgin., M., Çulha., M. \& Bat., L. (2001). On the Occurrence of Niphargus valachicus Dobreanu and Manolache, 1933 (Amphipodaa, Gammaridae) in the Western Black Sea Region of Turkey. Turkish Journal of Zoology 25, 235-239.

Akbulut, M., Öztürk, M. \& Öztürk, M. (2002). The Benthic Macroinvertebrate Fauna of Sarıkum Lake and Spring Waters (Sinop). Turkish Journal of Maritime and Marine Sciences, 8, 103-119.

Anonymous (2016). Surface Water Quality Management Regulation (SWQMR). The Republic of Turkish Official Gazette No. 29797, Ankara, Turkey

Armitage, P.D., Moss, D., Wright, J.F. \& Furse, M.T. (1983). The performance of a new biological water quality score system based on macroinvertebrates over a wide range of unpolluted running-water sites. Water Research, 17 (3), 333-347. DOI:10.1016/0043-1354(83)90188-4

Aydemir-Çil, E. (2014). Taxonomic and Ecological Assessment Of Macro Benthic Fauna Of Karasu Stream (Sinop). Sinop University, Institute of natural and Applied Sciences, Faculty of Fisheries, PhD thesis.

Bat, L., Akbulut, M., Çulha, M. \& Sezgin, M. (2000). The Macrobenthic fauna of Sırakaraağaçlar Stream flowing into the Black Sea at Akliman, Sinop. Turkish Journal of Maritime and Marine Sciences, 6, 71-86.

Bellan-Santini, D. (1969). Contribution à l'étude des peuplement infralittoraux sur substrat rocheux (Etude qualitative et quantitative de la franch Superiere). Recherche Travaux Station Marine Endoume, 63(47), 9294.

Benetti, C.J. \& Garrido, J. (2010). The influence of stream habitat and water quality on water beetles assemblages in two rivers in northwest Spain. Vie et milieu, 60(1), 53-63.

Bray, R.J. \& Curtis, J.T. (1957). An ordination of the upland forest communities of southern Wisconsin. Ecological Monographs, 27, 325349. DOI:10.2307/1942268
The members of the genus Gammarus constituted the dominant group at the station.

\section{CONCLUSIONS}

Karasu Stream is a suitable habitat for benthic macroinvertebrates in terms of its location, bottom structure, water quality, and other ecological characteristics. The biological monitoring studies should be carried out for the sustainable use of the Karasu Stream. In this way, biodiversity and water quality will remain at the desired level and its unique habitats can be protected from the destructive effects of human pressure and pollution.

\section{ACKNOWLEDGMENTS}

This study was financially supported by S.U. Scientific Research Council (BAP) (Project no: SÜF- 1901-12-12). The authors wish to thank Yakup ERDEM, Uğur ÇARLI, Ethem ERTAŞ and Erkut ÖZCAN for their help during the field studies and to BAP for their support.

Chapman, D. (1996). Water Quality Assessments - A Guide to Use of Biota, Sediments and Water in Environmental Monitoring - Second Edition. London: Cambridge Press.

Demir, Ö. (2005). Evaluation of water quality with macro invertebrates in sediment. Harran University, Department of Environmental Engineering, MSc thesis.

Ertorun, N. \& Tanatmış, M. (2004). Ephemeroptera (Insecta) Limnofauna of Karasu stream (Sinop), Anadolu University Journal of Science and Technology, 5(1), 107-114.

Fauna Europea (2021). https://fauna-eu.org/

Hopkins, C. (1971). The annual temperature regime of a small stream in New Zealand. Hydrobiologia, 37, 397-408. DOI:10.1007/BF00018811

Kovach, W.L. (1998). MVSP, A Multivariate Statistical Package for Windows, ver. 3.1. Pentraeth: Kovach Computing Services.

Letovsky, E., Myers, J.E., Canepa, A. \& McCabe, D.J. (2012). Differences between kick sampling techniques and short-term Hester-Dendy sampling for stream macroinvertebrates. Bios, 83(2), 47-55. DOI:10.1893/0005-3155-83.2.47

N.A.S. (1972). A report of the Committee on Water Quality Criteria. Washington D.C.: US Government Printing Office.

Öktener, A. (2004). A preliminary research on Mollusca species in some freshwater in Sinop and Bafra. Gazi Universitesi Fen Bilimleri Dergisi. 17(2): 21-30.

Paisley, M.F., Trigg, D.J. \& Walley, W.J. (2013). Revision of the biological monitoring working party (BMWP) score system: derivation of presentonly and abundance-related scores from field data. River Research and Applications, 30(7), 887-904. DOI:10.1002/rra.2686

Pielou, E.C. (1975). Ecological diversity. New York: Wiley.

Shannon, C.E. \& Weaver, W. (1949). The Mathematical Theory of Communication, University of Illinois Press, Urbana.

Soyer, J. (1970). Bionomie benthique du plateau continental de la côte catalane française. III. Les peuplements de Copepodes harpacticoides (Crustacea). Vie et Milieu, 21, 337-511.

Subba Rao, N.V. (1989). Handbook of Freshwater Molluscs of India. Calcutta: Director Zoological Survey of India. 
Şendoğan, E. (2006). A research on the Macrobenthic fauna of Sarikum Lake. Ondokuz Mayıs University, Institute of Natural and Applied Sciences, MSc thesis.

Tanatmış, M. (2004). Ephemeroptera (Insecta) fauna of the coastal region between Gökırmak River Basin (Kastamonu) and Cide (Kastamonu)Ayancık (Sinop). Turkish. Entomology Journal, 28 (1), 45-56.

Tanatmış, M. \& Ertorun, N. (2008). Ephemeroptera (Insecta) Limnofauna of the Kabali stream (Sinop) Basin. Journal of Fisheries Sciences, 2 (3); 329-331. DOI:10.3153/jfscom.mug.200720

Tanyolaç, J. (2004). Limnoloji. Ankara: Hatipoğlu Yayınevi.

Thorne, R.S. \& Williams, W.P. (1997). The response of benthic macroinvertebrate to pollution in developing countries: A multimetric system of bioassessment. Freshwater Biology, 13(1), 57-73. DOI:10.1046/j.1365-2427.1997.00181.x
Ward, J.V. (1985). Thermal characteristics of running waters. In: BR Davies, RD Walmsley (eds) Perspectives in Southern Hemisphere Limnology. Developments in Hydrobiology, 28, 31-46. DOI:10.1007/BF00045924

Yardım, Ö., Şendoğan, E., Bat, L., Sezgin, M. \& Çulha, M (2008). Lake Sarikum (Sinop) Macrobenthic Mollusca and Crustacea fauna. Ege University Journal of Fisheries \& Aquatic Sciences, 25(4), 301-309.

Yardım, Ö., Erdem, Y., Bat, L. \& Aydemir, Çil, E. (2017). The Erfelek Stream and Ecological Importance. Alınteri Journal of Agricultural Sciences, 32(2), 91-94. DOI:10.28955/alinterizbd.342467

Zamora-Muñoz, C. \& Alba-Tercedor, J. (1996). Bioassessment of organically polluted Spanish rivers, using a biotic index and multivariate methods. Journal of the North American Benthological Society, 15, 332-352. DOI:10.2307/1467281 